\title{
Business Environment Factors, Incoterms Selection and Export Performance
}

\author{
Nicolas Hien \\ Groupe 4L ${ }^{2}$ Inc., C.P. 24239, 232, St-Charles, Ste-Thérèse, QC, Canada J7E 5T8 \\ nhien@groupe4l2.com
}

\section{Gilbert Laporte}

Canada Research Chair in Distribution Management, HEC Montréal, 3000 chemin de la Côte-Sainte-Catherine, Montréal (Québec) Canada H3T 2A7

gilbert@crt.umontreal.ca

Jacques Roy*

Logistics and Operations Management Department, HEC Montréal, 3000 chemin de la Côte-Sainte-Catherine, Montréal (Québec) Canada H3T 2A7

jacques.roy@hec.ca

\begin{abstract}
The objective of this study is to identify the main factors taken into consideration when deciding which Incoterms to use and to analyze the impact of the choices of Incoterms on export performance. The results highlight the importance of considering both the internal and external business environments in the selection process for Incoterms and its contribution to improved export performance. In addition, this article shows the importance of training to increase the awareness of the strategic dimension of Incoterms and to promote the utilization of Incoterms which also enhance export performance.
\end{abstract}

Keywords: incoterms selection, export performance, business environment factors

\section{Introduction}

The procurement and distribution of goods has been significantly influenced by the globalization and liberalization of markets. With the advent of trade liberalization and the emergence of economies such as Brazil, Russia, and India, global supply chains within many industries have and continue to change drastically. Distribution and supply networks must be reconfigured and re-optimized as a result of mergers and acquisitions taking place in this new econoc environment. Furthermore, distribution networks must sometimes be redesigned in order to satisfy increasingly complex demands from customers and retailers. According to the OECD (2002), "Global supply chains are worldwide networks of suppliers, manufacturers, warehouses, distribution centers and retailers through which raw materials are acquired, transformed and delivered to customers."

To remain competitive on a truly global stage, companies are looking for new partners that can generate savings in operating costs and they are

*Corresponding Author 
finding them in Asia, notably. This practice, sometimes called "off-shoring" or "global sourcing" often results in trading savings in operating cost for increases in transportation, inventory and handling costs. Companies are also increasingly focusing on their core competencies, be it the manufacturing or assembly of goods (e.g. the auto industry) or the design and marketing of products (e.g., Nike). Those core competencies seldom include the supply and distribution of goods, and these activities are therefore increasingly outsourced to third party organizations that specialize in logistics, namely 3PLs. In this context, it is important to understand the rules governing international trade and how responsibilities are shared among individual members taking part in global supply chains. This is where Incoterms come into play.

Incoterms are defined as a set of international rules for interpreting the stipulations in international sales contracts. In the field of international transportation, Incoterms are used to establish the respective responsibilities of the signatories. The selection of Incoterms is often viewed as a difficult decision because of the general lack of knowledge on the subject and because the choice of appropriate Incoterms tends to be considered as a constraint rather than as an opportunity to improve the efficiency of an international deal. According to the experts we have consulted, Incoterms are not very well known by the different actors along the supply chain including shippers and carriers. The purpose of this paper is to identify the main factors taken into consideration when deciding which Incoterms to use and to analyze the impact of these choices on export performance.

This study should increase the knowledge and, more importantly, the understanding of a topic that has until now been the subject of very few scientific publications. Although the business literature frequently refers to Incoterms, these terms have been virtually ignored in the academic world despite their strategic importance (Gooley, 2000). Also, Jacquet (2000) expressed surprise that, despite the phenomenon of globalization and the growth in trade, Incoterms were still relatively unknown. This study should not only establish the theoretical foundations essential to any future research development in this area, but it should also highlight the connection between Incoterms selection and export performance.

\section{Literature Review and Research Fondations}

\subsection{Incoterms}

A contraction of the expression "INternational COmmercial TERMS", the word "Incoterms" refers to a group of rules proposed by the International Chamber of Commerce (ICC). These rules define the rights and obligations of buyers and sellers precisely, in a codified language, in the context of international trade (Jimenez, 1998; Chevalier, 2000; Gooley, 2000; Jacquet, 2000). In addition, they define the cost transfer and the risk transfer points associated with a shipment (Sriro, 1993; Legrand \& Martini, 1999; Chevalier, 2000).

According to Jimenez (1998), Incoterms address three fundamental questions: 1) Who is responsible for transportation costs? 2) At what point in the transaction is the risk (loss or deterioration) transferred? and 3) Who is responsible for the import and export customs formalities? For Chevalier (2000), Incoterms essentially allow several elements to be precisely defined: the seller's delivery obligations, the risk transfer from the seller to the buyer, the distribution of costs between the two parties, and the responsibility for the transportation documents.

Recognized worldwide by governments, legal authorities, and transportation professionals, the use of Incoterms is however not obligatory. Incoterms are a tool offered to companies which can, theoretically at least, choose to use them or not. Still, the absence of an Incoterm in a contract can cause significant problems when determining the customs value of the merchandise, leading the authorities of a large number of countries, such as Morroco or Algeria, to require their use, thus making them quasi-compulsory (Chevalier, 2000).

According to Holley \& Haynes (2003), knowledge and understanding of Incoterms is vital in international trade. Due to their widespread use, Incoterms have become more and more important; in fact, Freudmann (1999)_considered them to be the "Bible of international commerce". Incoterms reduce the uncertainty due to the high degree of heterogeneity in international commercial practices by creating a common frame of reference for the signatories (Gooley, 2000). Thus, the terms provide 
Table 1. Presentation of the thirteen Incoterms

\begin{tabular}{|l|l|}
\hline Acronym & Complete Name \\
\hline EXW & Ex-Works \\
FAS & Free Alongside Ship \\
FCA & Free-Carrier \\
FOB & Free On Board \\
CFR & Cost and FReight \\
CPT & Carriage Paid To \\
CIF & Cost, Insurance, Freight \\
CIP & Carriage Insurance Paid \\
DAF & Delivered At Frontier \\
DES & Delivered Ex Ship \\
DEQ & Delivered Ex Quay \\
DDU & Delivered Duty Unpaid \\
DDP & Delivered Duty Paid \\
\hline
\end{tabular}

a particularly useful structure during the negotiation phase, in that they save time and they tend to clarify the respective responsibilities of the two parties (Sriro, 1993).

Incoterms are also important because those who use them judiciously can potentially increase their profits. According to Gooley (2000), North-American companies involved in international trade would benefit enormously by increasing their knowledge of Incoterms. This tacit link between Incoterm choice and performance, which will be developed later in this article, has also been highlighted by Jacquet (2000) who considers Incoterms to be a factor in improving competitiveness and an important source of company profitability. Clearly, the correct choice of Incoterms can have an impact on the success or failure of an international sales contract.

\subsection{Presentation of the thirteen Incoterms}

The list of Incoterms, last revised in 2000, currently includes 13 terms (see Table 1), expressed as acronyms, which are generally divided into 4 groups: $\mathrm{E}$ (EXW), F (FCA, FAS, and FOB), C (CPT, CFR, CIP, and CIF) and D (DAF, DES, DEQ, DDU, and DDP). The first three groups are called departure Incoterms and the Incoterms in the last group, D, are called arrival Incoterms (DeBattista, 1995; Jimenez, 1998; Legrand \& Martini, 1999; Ramberg, 1999; Chevalier, 2000). The distribution of buyer/seller costs for each Incoterm is provided in Table 2.

Table 2. Buyer/seller cost distribution according to the Incoterm chosen

\begin{tabular}{|c|c|c|c|c|c|c|c|c|c|c|c|}
\hline Acronym & Packing & \begin{tabular}{|c|} 
Loading \\
Containeri- \\
zation
\end{tabular} & $\begin{array}{c}\text { Pre- } \\
\text { Carriage }\end{array}$ & $\begin{array}{c}\text { Customs } \\
\text { Export } \\
\text { Formalities }\end{array}$ & $\begin{array}{c}\text { Airport transit/ } \\
\text { Consolidation } \\
\text { platform } \\
\text { Departure }\end{array}$ & $\begin{array}{c}\text { Principal } \\
\text { Transportation }\end{array}$ & $\begin{array}{c}\text { Transportation } \\
\text { Insurance }\end{array}$ & $\begin{array}{l}\text { Airport transit/ } \\
\text { Consolidation } \\
\text { platform } \\
\text { Arrival }\end{array}$ & $\begin{array}{l}\text { Customs } \\
\text { Export } \\
\text { Formalities } \\
\text { Duties and } \\
\text { taxes }\end{array}$ & $\begin{array}{c}\text { Post- } \\
\text { Carriage }\end{array}$ & Unloading \\
\hline EXW & $S$ & B & B & B & B & B & B & B & B & B & B \\
\hline FAS & $S$ & S & S & S & B & B & B & B & B & B & B \\
\hline FCA & $S$ & S & S & S & B & B & B & B & B & B & B \\
\hline FOB & $S$ & $S$ & $S$ & $S$ & $S / B$ & B & B & B & B & B & B \\
\hline CFR & S & S & S & S & S & S & B & B & B & B & B \\
\hline СРT & $S$ & S & S & S & S & S & B & B & B & B & B \\
\hline $\mathrm{CIF}$ & S & S & S & S & S & S & S & B & B & B & B \\
\hline CIP & S & $S$ & $S$ & $S$ & $S$ & $S$ & $S$ & B & B & B & B \\
\hline DAF & $S$ & $S$ & $S$ & S & $S$ & $S / B$ & $S / B$ & B & B & B & B \\
\hline DES & $S$ & $S$ & $S$ & $S$ & $S$ & $S$ & $S$ & B & B & B & B \\
\hline DEQ & S & S & S & S & S & S & S & S & B & B & B \\
\hline DDU & $S$ & S & $S$ & $S$ & $S$ & S & S & $S$ & B & S & B \\
\hline DDP & $S$ & $S$ & $S$ & $S$ & $S$ & $S$ & $S$ & $S$ & $S$ & $S$ & B \\
\hline
\end{tabular}




\subsection{Business Environment factors}

When selecting Incoterms, firms aim to maximize their profits while minimizing uncertainty and risks related to an international transaction. In order to select the most appropriate Incoterm for a given export or import situation, a company must clearly understand the business environment factors that affect this decision. The business environment can be defined either as the set of forces to which the company must respond (Lawrence \& Lorsch, 1967; Anderson \& Paine, 1975) or as the set of factors that tend to influence an organization (Dill, 1958; Aharoni et al., 1978). The business environment is studied in order to identify the set of relevant environmental factors for a specific context. Several authors (e.g., Luffman, 1996; Lynch, 1997; and Walsh, 2005) have used the PESTEL method to analyze the Political, Economic, Social, Technological, Environmental/Ecological and Legal characteristics of the environment in which a company operates (Sanchez \& Heen, 1997).

Given the absence of studies related to the business environment factors impacting on Incoterm choices, we have examined the literature in a related domain, the market entrance mode choice, which is similar to the Incoterm choice, in that such characteristics as international context or market knowledge are important in both domains. Legrand \& Martini (1999) have shown that Incoterm choice is influenced by a certain number of factors which are quite similar to those taken into consideration when deciding how to penetrate a foreign market.

In the literature dealing with the business environment factors that influence market entrance mode choices, several factors are regularly mentioned. For example, a number of authors including Sanjeev \& Sridhar (1992), Brouthers (1995), Tsé et al. (1997), Pan \& Tsé (2000), Osland et al. (2001) and Rasheed (2005), have considered the risk inherent to the destination country as a fundamental factor in choosing the entrance mode. Other factors have also been suggested, such as the size, resources or negotiating power of the company, the degree of competitiveness and the regulatory measures of the target market, the product characteristics, or the company's international experience and knowledge of the target market. In addition, the important review work of Erramilli (1992) and Mayrhofer (2002) has led to a classification of environmental factors relevant to the entrance mode choice. Also, Duncan (1972) has identified several environmental factors using 19 semi-structured interviews with individuals from various hierarchical levels. Based on Duncan's study and our review of the literature, we have built a list of the environmental factors that should be considered when choosing Incoterms. This list was validated by an expert panel regrouping seven Incoterms specialists (See Figure 1). The expert panel composition is provided in the methodology section.

\subsection{Export Performance}

The first study of export performance is generally attributed to Tookey (1964) who attempted to identify the key elements for export success. In the years that followed, many studies focusing primarily on export performance indicators or their determinants were published. Given the complexity of this field of research with its frequently contradictory results (e.g., Zou \& Stan, 1998; Katsikeas et al., 2000; Ali, 2004), several authors have worked to synthesize and classify the publications in this domain: Madsen (1989); Aaby \& Slater (1989); Chetty et Hamilton (1993); Zou \& Stan (1998) and Katsikeas et al. (2000).

In their review of 103 articles, Katsikeas et al. (2000) demonstrated the total heterogeneity of the existing measurement indicators, which they grouped into three categories: economic indicators, non-economic indicators and all-purpose indicators. In all, the authors listed 42 different indicators used to measure export performance: 23 economic, 14 non-economic and five all-purpose. However, only six of these seem to appear with any regularity: export sales figures, export sales growth, export profitability, the proportion of export sales, manager satisfaction with export activities, and manager perceptions of export performance. Given that these indicators appear to be the most used, our discussion will focus on these, examining their use more closely.

The first of these six indicators, export sales figures, remains the most widely used in the various studies, and appears to be the key indicator when only one is chosen to evaluate export performance, as was the case in the research by Calantone et al. (2006). This indicator provides information about a situation at a precise moment in time and is often coupled with export sales growth figures which allow 
the evolution of export sales to be integrated into export performance, thus providing a less static picture of the situation (Zou et al., 1998). Another indicator, this one financial, is export profitability, which serves to evaluate the profits resulting from exports; this indicator is expressed most often as a percentage of the total profit. The fourth indicator is the proportion of export sales, expressed as the ratio of export sales to total sales. This indicator is also called "export intensity".

The last two indicators are more subjective, relying on management judgment to evaluate export performance. The first of these subjective indicators targets the degree of manager satisfaction with export performance. According to White et al. (1998), the use of this indicator is coherent with "management by objective" and constitutes a pertinent measurement of export performance. The second, manager perceptions of export performance, has figured in many studies including those by Thirkell \& Dau (1998); Zou et al. (1998) and Baldauf et al. (2000). Over the years, some authors (Dominguez and Seiqueira, 1993; Katsikeas et al., 1996) have stressed the necessity of using a combination of objective and subjective measurements to evaluate export performance.

Finally, Zou et al. (1998) proposed the EXPERF tool for evaluating export performance. They focused on three groups of performance measurements: financial performance, strategic performance and satisfaction with export performance. The authors have underlined the adaptability of their tool, whose objective is to standardize the measurement indicators in export performance studies, thus making it possible to compare the different studies. Used in several studies (see for example, Lages and Montgomery, 2004 or Ali, 2004), EXPERF integrates all of the indicators most frequently found in the literature, except one: the proportion of export sales, or export intensity. However, this indicator has often been criticized because, in the opinion of the critics, it is not an export performance indicator, but rather a method for evaluating a company's level of internationalization (Cooper \& Kleinschmidt, 1985; White et al., 1998). Given the pertinence of this tool, its relative simplicity of use and its suitability for studies based on questionnaires, EXPERF was adapted to evaluate the export performance of the companies considered in this study (see Table 3). The tool thus structured our research. Specifically, our questionnaire included the nine questions proposed by Zou et al., with answers along a Likert scale from 1 to 5 , ranging from "disagree totally" to "agree totally".

Table 3. The EXPERF tool for evaluating export performance

\begin{tabular}{|l|}
\hline FP- Financial Performance \\
Export activities: \\
FP 1: were profitable \\
FP 2: generated a high volume of sales \\
FP 3: grew rapidly \\
\hline SP- Strategic Performance \\
Export activities: \\
SP 1: increase our competitivity \\
SP 2: reinforce our strategic position \\
SP 3: increase our market shares \\
\hline ES- Satisfaction with Export Activities \\
ES 1: export activities have proved satisfactory \\
ES 2: export activities have been successful \\
ES 3: export activities have satisfied our expectations \\
\hline
\end{tabular}

\subsection{Research foundations}

As shown in Figure 1, the hypotheses on which this study is based can be grouped in two categories: preliminary hypotheses $(\mathrm{PH})$, which target a general understanding of Incoterm use, their importance to companies and the knowledge that most companies have of them; and working hypotheses (WH), which respond directly to the fundamental question of this study which is to identify the main factors taken into consideration when deciding which Incoterms to use and to analyze the impact of the choices of Incoterms on export performance. Each hypothesis is stated formally in Table 4.

\section{Methodology}

The data in this study come from two main sources; the first one being interviews of seven Incoterms experts. The selection of the expert panel was based on the following criteria. The first requirement was the reputation of the expert; he had to be recognized 
Table 4. Formal statement of the hypotheses

\begin{tabular}{|c|c|}
\hline Hyphotesis & Statement \\
\hline PH1 & Companies that use Incoterms more frequently have a better export performance. \\
\hline $\mathrm{PH} 2$ & Companies with a greater knowledge of Incoterms have a better export performance. \\
\hline PH3 & Companies that accord more importance to Incoterms have a better export performance. \\
\hline $\mathrm{PH} 4$ & Companies that choose their own Incoterms have a better export performance than those that leave Incoterm choice to a third party. \\
\hline WH1 & $\begin{array}{l}\text { Companies that take their international experience and that of their managers into consideration when selecting Incoterms have a better export } \\
\text { performance than those that do not. }\end{array}$ \\
\hline WH2 & Companies that take shipment value into consideration when selecting Incoterms have a better export performance than those that do not. \\
\hline WH3 & $\begin{array}{l}\text { Companies that base their choice of Incoterms on customary practice rather than environmental analysis have a worse export performance than } \\
\text { those that take the pertinent environmental factors into account }\end{array}$ \\
\hline WH4 & $\begin{array}{l}\text { Companies that take their financial resources (working capital) into consideration when selecting Incoterms have a better export performance than } \\
\text { those that do not. }\end{array}$ \\
\hline WH5 & $\begin{array}{l}\text { Companies that take client negotiating power into consideration when selecting Incoterms have a better export performance than those that do } \\
\text { not. }\end{array}$ \\
\hline WH6 & $\begin{array}{l}\text { Companies that take the chosen mode of transportation into consideration when selecting Incoterms have a better export performance than those } \\
\text { that do not. }\end{array}$ \\
\hline WH7 & $\begin{array}{l}\text { Companies that take their client's characteristics into consideration when selecting Incoterms have a better export performance than those that do } \\
\text { not. }\end{array}$ \\
\hline WH8 & $\begin{array}{l}\text { Companies that take the risks inherent to the destination country into consideration when selecting Incoterms have a better export performance } \\
\text { than those that do not. }\end{array}$ \\
\hline WH9 & $\begin{array}{l}\text { Companies that take the competitive intensity in the destination country into consideration when selecting Incoterms have a better export performance } \\
\text { than those that do not. }\end{array}$ \\
\hline WH10 & $\begin{array}{l}\text { Companies that take the regulations of the destination country into consideration when selecting Incoterms have a better export performance than } \\
\text { those that do not. }\end{array}$ \\
\hline WH11 & $\begin{array}{l}\text { Companies that take pertinent environmental factors into consideration when selecting Incoterms have a better export performance than those } \\
\text { that do not. }\end{array}$ \\
\hline
\end{tabular}

as an Incoterm specialist. In addition, the expert panel had to come from different sectors in order to provide a large overview of the subject. The composition of the expert panel was as follows: One senior manager from a very large international 3PL/ integrator, one international specialist working for a transportation company, two export senior managers, two export consultants and trainers, and finally, one senior manager with an export trade association. Those interviews helped us build the questionnaire and validate the environmental factors identified at the literature review stage. The second source of data was the questionnaire that constituted the basis of the statistical analysis. This methodology is relatively frequently used in several research sectors. For instance, Lin (2006) used such a methodology in the logistics sector.

\subsection{Questionnaire administration}

Since our target population was exporting companies in Quebec, we sent our questionnaire to an appropriate sample culled from the Industry Canada database. This database, like that of the CRIQ (Centre de Recherche Industrielle du Québec: Quebec Industrial Research Center), has the advantage of containing only companies that have registered voluntarily. From this database, we obtained the eaddresses of the export managers of 1308 companies situated in Quebec and engaging in export activities.

The questionnaire was pre-tested on five people, three times in the form of an interview and twice electronically, the latter replicating the conditions of the real study. In order to conform to the protocol analysis methods suggested by Malhotra et al. (2004), during interviews we used the "thinking out loud" method, which consists of asking respondents to 
voice their thoughts out loud as they are filling out the questionnaire. These comments are recorded, thus allowing the reactions to be analyzed later on, which in turn makes it possible to clarify the response if necessary. Those participating in the pre-testing phase confirmed that all the questions were clear; the interviews helped to make sure that the respondents interpreted the questions as intended, and the electronic pre-tests confirmed that the technological support functioned as it was supposed to.

In this study, 135 out of the 1308 export managers contacted completed the questionnaire, for a response rate of $10.32 \%$. The number of respondents compares favorably with that reported in similar studies. However, the relatively low response rate will incite to exercise caution when generalizing the results to the whole population of companies engaged in export activities.

According to Statistics Canada, small and medium size enterprises (SME's) have less than 500 employees and generate less than 50 million dollars in revenues. The majority of our respondents (55.3\%) are companies having between 11 and 99 employees, 25.5\% have between 100 and 499 employees and $14.9 \%$ have 10 employees or less. This leaves $4.3 \%$ of the respondents with 500 employees or more. Revenue wise, the majority of respondents (58.7\%) generate between 0.5 and 15 million dollars, 25.8\% between 15 and 50 million dollars, and $5.8 \%$ of companies report revenues less than 0.5 million dollars, leaving $9.7 \%$ of respondents with revenues exceeding 50 million dollars annually. With $89.6 \%$ of our respondents coming from small and medium size enterprises (SME's) according to Statistics Canada's definition, our sample closely reflects the Quebec population of export companies of which 93\% are SME's. It is interesting to note that we did not find any statistically significant difference related to company size in our results.

Most of the respondents (65\%) come from the manufacturing sector, the others represent wholesale and retail $(8.9 \%)$, agriculture and forestry $(6.4 \%)$, mining $(3.2 \%)$ and other sectors. Respondents are mostly experienced managers. Indeed, one third have more than 20 years of experience in export activities and $50 \%$ possess between 6 and 20 years of experience. Respondents are relatively high in the hierarchy of their organizations. This may be explained by the high proportion of SME's in our sample. Almost one quarter of the respondents are top managers, $42 \%$ are senior managers and $29 \%$ are managers.

\subsection{Validation and reliability of measurements}

First, data analysis for this research was performed using the version 12 of the SPSS ${ }^{\mathrm{TM}}$ software. A Cronbach Alpha test was conducted to measure the reliability of our scales. The results are presented in Table 5. It is generally agreed that a Cronbach Alpha in the range of 0.600 to 0.700 is the minimum required to indicate a reliable construct and that the closer to 1.000 the result, the more it becomes reliable. From Table 5, we find that for each category, the scales used show an excellent degree of internal consistency, greatly exceeding 0.600 and reaching 0.934 in the case of strategic performance and 0.960 for satisfaction with regard to export.

Table 5. Reliability of measurement scales

\begin{tabular}{|l|r|c|c|}
\hline \multicolumn{1}{|c|}{ Scales } & $\begin{array}{c}\text { Corresponding } \\
\text { Questions }\end{array}$ & $\begin{array}{c}\text { Number of } \\
\text { Elements }\end{array}$ & $\begin{array}{c}\text { Cronbach } \\
\text { Alpha }\end{array}$ \\
\hline Knowledge and importance & 2.4 to 2.7 & 4 & 0,867 \\
Environmental Factors & 3.2 .1 to 3.2 .10 & 10 & 0,838 \\
Financial Performance & 5.1 to 5.3 & 3 & 0,764 \\
Strategic Performance & 5.4 to 5.6 & 3 & 0,934 \\
Satisfaction with Respect to Export & 5.7 to 5.9 & 3 & 0,960 \\
\hline
\end{tabular}

In order to address the non-response bias, we have compared the results obtained from the first respondents to those obtained at the end of the survey period. This method, called extrapolation, is used quite often in similar studies (see for example Krause and Scannell, 2002). We have thus compared the results obtained from the first ten respondents to those of the last ten. Tests based on the Student Law (t-tests) were conducted on ten questions randomly selected in the questionnaire and no significant differences were observed, thereby confirming the absence of non-response bias in this study. 


\section{Results}

Figure 1 presents the hypotheses that were formulated for this study. Statistical analysis methods were used to test each of the successive hypotheses, beginning with the four preliminary hypotheses and ending with the eleven working hypotheses.

\section{Preliminary Hypothesis 1: Correlation between Incoterm use frequency and export performance}

The first preliminary hypothesis shown in Figure 1 is as follows: "Companies that use Incoterms more frequently have a better export performance." Linking each of the individual aspects of export performance to Incoterm use frequency highlights three significant relationships. Incoterm use frequency appears to be linked to the three variables that measure manager satisfaction with export activities: "satisfactory" ( $p=0.022)$, "successful" $(p=0.004)$, and "satisfied expectations" ( $p=0.045)$.

Even though the three aspects of financial performance and strategic performance are not individually linked to use frequency, the average value nonetheless indicates a significant correlation, with a $p$-value of 0.011 for financial performance and 0.034 for strategic performance. In addition, the values found by the statistical analysis reveal a correlation between "Incoterm use frequency" and each aspect of the category "satisfaction with export activities". It is therefore not surprising that the correlation is strongest for the aggregated results, $(p=0.001$ and $\eta=0.353$ ). Finally, Incoterm use frequency is also connected to overall export performance $(p=0.008)$.

Consequently, it seems that the first preliminary hypothesis can be validated, since it appears that companies that use Incoterms more frequently have a better export performance.

\section{Preliminary Hypothesis 2: Correlation between Incoterm knowledge and export performance}

The second preliminary hypothesis is as follows: "Companies with a greater knowledge of Incoterms have a better export performance." Numerous aspects of export performance are linked to the knowledge of Incoterms. Specifically, six of the nine aspects have a fairly strong significant correlation.
Sales volume $(p=0.000)$, satisfied expectations $(p=0.002)$ and strategic position $(p=0.004)$ have the strongest correlation; however, growth $(p=0.014)$, satisfaction $(p=0.038)$, and competitiveness $(p=0.046)$ also have $p$ values under the threshold of statistical significance. Thus, we can state that the variable "Incoterm knowledge" explains $8.4 \%$ of the "export performance" variable in terms of strategic position, $9.9 \%$ in terms of satisfied expectations, and $14.6 \%$ in terms of sales volume.

Like use frequency, knowledge of Incoterms is linked to financial performance $(p=0.001)$, strategic performance $(p=0.035)$, satisfaction with export activities $(p=0.019)$ and overall performance $(0.004)$. In addition, according to the correlation coefficients, the "Incoterm knowledge" variable alone explains $8.3 \%$ of the overall performance, $4.67 \%$ of the strategic performance and $5.6 \%$ of the satisfaction with export activities. The strongest correlation $(10.7 \%)$ is between Incoterm knowledge and financial performance.

Consequently, the results of the statistical analysis allow the validation of the second preliminary hypothesis, highlighting the fact that companies with a greater knowledge of Incoterms have a better export performance.

\section{Preliminary Hypothesis 3: Correlation between the importance accorded to Incoterms and export performance}

The third preliminary hypothesis is stated as follows: "Companies that accord more importance to Incoterms have a better export performance." Eight of the nine aspects of export performance are linked to the importance accorded to Incoterms. Thus, only growth does not seem to have a significant correlation with the importance accorded to Incoterms. However, although the correlation with some of the aspects is fairly weak, sales volume and strategic position both have a stronger correlation. In fact, the importance accorded by companies to Incoterms explains $12.7 \%$ of export performance in terms of sales volume and $8.7 \%$ in terms of strategic position.

Studying the aggregated results shows that the importance accorded to Incoterms seems to be linked as much to financial performance $(p=0.006)$ as to strategic performance $(p=0.004)$ or the satisfaction with export activities $(p=0.019)$. 
Thus, it is possible to validate the third preliminary hypothesis, concluding that the companies that accord more importance to Incoterms have a better export performance.

\section{Preliminary Hypothesis 4: Correlation between who makes the Incoterm decision and export performance}

The fourth preliminary hypothesis states that "companies that choose their own Incoterms have a better export performance than those that leave Incoterm choice to a third party". A chi-squared-test of the various aspects of export performance shows that only sales volume with a $p$-value of 0.030 appears to be correlated (Cramer's $V=0.339$ ) to whether the decision-making was internal or external. In addition, the fact that a company chooses its Incoterms for itself does not seem to be linked to strategic performance, satisfaction with export activities, or overall performance. Only financial performance seems to be connected to this decision-making aspect $(p=0.044)$.

Thus, we can neither reject the hypothesis, nor conclude that companies that choose their own Incoterms have a better export performance than those that leave Incoterm choice to a third party.

Working Hypotheses 1 to 10: Correlation between the consideration of environmental factors and export performance

The first ten working hypotheses (WH) all concern the correlation between business environmental factors and export performance. These hypotheses were designed to determine whether companies that consider each environmental factor when selecting Incoterms have a better export performance than those that do not.

The statistical analysis shows that five of the ten environmental factors are linked to at least one aspect of export performance. Clearly, growth can be connected to both consideration of shipment value $(p=0.041)$ and consideration of client characteristics $(p=0.045)$. The latter factor is also clearly linked to strategic position $(p=0.046)$. Considering international experience when selecting Incoterms is correlated to seven of the nine export performance aspects, including particularly strong correlations with both strategic position $(p=0.001)$ and satisfied expectations $(p=0.000)$. After international experience, it is client negotiating power that is connected to the greatest number of export performance aspects (six aspects), followed by competitive intensity (five aspects).

The analysis of the correlation coefficients $R^{2}$ shows that considering international experience alone accounts for $12.5 \%$ of the export performance in terms of satisfied expectations, $10.4 \%$ in terms of strategic position, and $7.9 \%$ in terms of market share. Several other correlations are also worth mentioning, such as consideration of client negotiating power and competitive intensity, which explain, respectively, $7.8 \%$ and $4.7 \%$ of export performance in terms of sales volume and $5.8 \%$ and $8 \%$ in terms of strategic position.

As was done when validating the preliminary hypotheses, it is useful to divide the nine performance aspects into three distinct categories: financial performance, strategic performance, and satisfaction with export activities. Three environmental factorsinternational experience, client negotiating power and competitive intensity-seem to be connected to the three categories of export performance; shipment value and client characteristics, which are weakly linked to growth and strategic position, do not appear to be significantly correlated. Thus, international experience explains $8.9 \%$ of the satisfaction with export activities, $7.8 \%$ of the strategic performance, and $5 \%$ of the financial performance. Consideration of client negotiating power is linked to financial performance $(p=0.0008)$ and to satisfaction with export activities $(p=0.016)$, while consideration of competitive intensity explains $6.1 \%$ of the financial performance and $7.2 \%$ of the strategic performance.

Figure 1 shows that, in terms of overall performance (the average export performance for the ten environmental factors), it is international experience $(p=0.001)$, client negotiating power $(p=0.015)$, and competitive intensity $(p=0.037)$ that are most strongly correlated with export performance, explaining respectively $10.3 \%, 6 \%$, and $4 \%$ of the overall performance.

It would seem, then, that companies that consider international experience, client negotiating power and the competitive intensity in the destination country when selecting Incoterms have a better export performance than those that do not. The working hypotheses 1,5 and 9 are thus validated, while the working hypotheses $2,3,4,6,7,8$, and 10 are not. 


\section{Working Hypothesis 11: Correlation between consideration of the environment and export performance}

This final working hypothesis, based on the average of the values for all of the environmental factors, except customs and practices, is stated as follows: Companies that take pertinent environmental factors (all factors except the habits and practices of the organization) into consideration when selecting Incoterms have a better export performance than those that do not.

An in-depth analysis shows there is a correlation between the consideration of environmental factors and the following aspects of export performance: growth, $(p=0.011)$ competitiveness $(p=0.023)$, strategic position $(p=0.005)$ and successful export activities $(p=0.041)$.

From these results, it appears that environmental factors are correlated to financial performance
( $p=0.036)$, strategic performance $(p=0.014)$, and overall performance $(p=0.024)$. Thus, considering pertinent environmental factors explains $4.9 \%$ of a business's financial performance from exports, $6.6 \%$ of their strategic performance, and $5.4 \%$ of their overall performance. However, considering environmental factors does not seem to influence manager satisfaction with export activities.

Consequently, this final hypothesis can also be validated and we can affirm that companies that take pertinent environmental factors into consideration when selecting Incoterms have a better export performance than those that do not. However, since this research is based on survey data and it does not track the performance of companies over years, we could not perform causality tests. Figure 1 summarizes our findings on the validation of the preliminary and working hypotheses.

Figure 1. Validation of the preliminary and working hypotheses

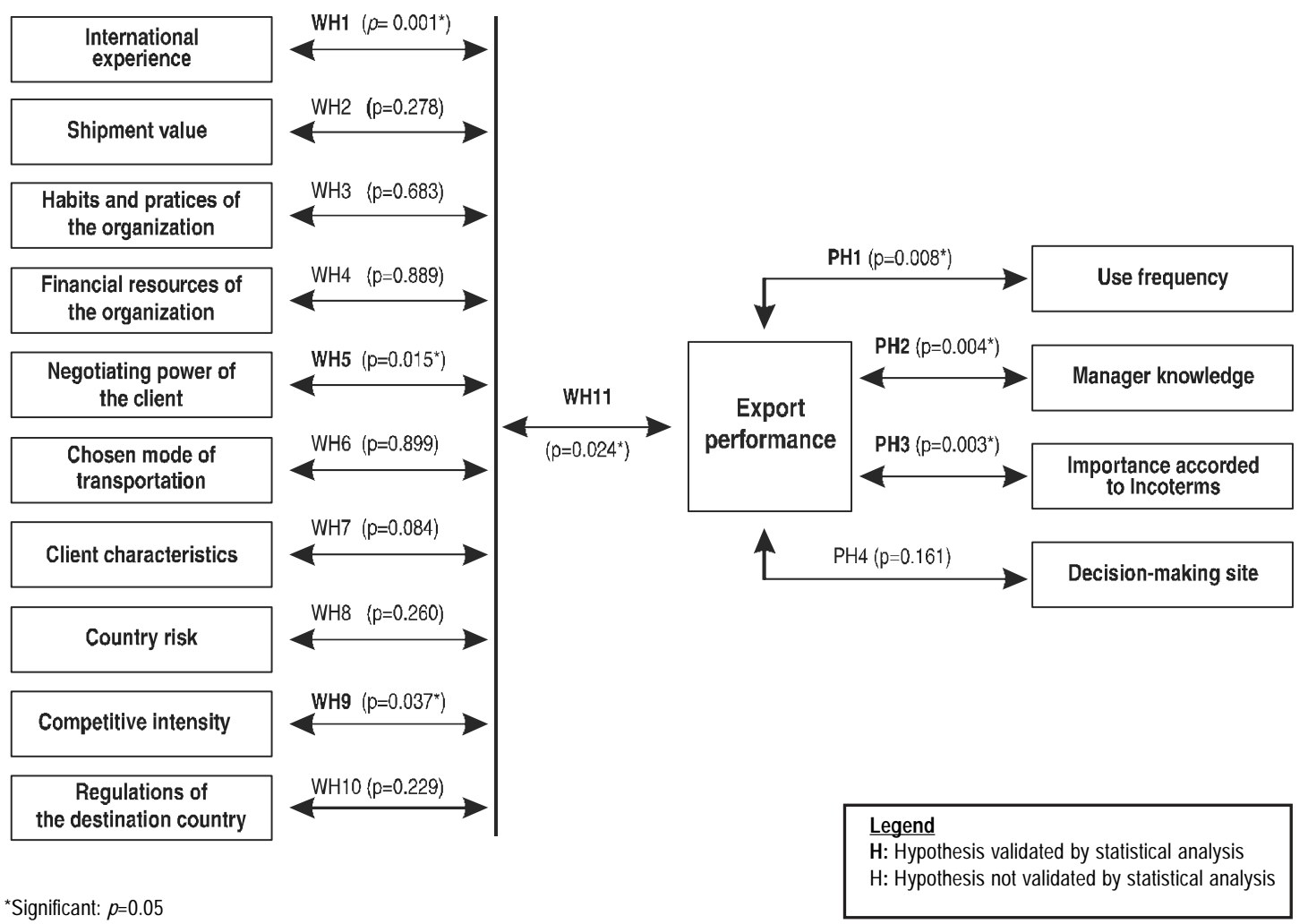




\section{Discussion}

\subsection{Analysis of the preliminary hypotheses}

As shown in Figure 1, the first three preliminary hypotheses could be validated by statistical analysis. Clearly, use frequency, Incoterm knowledge, and the importance accorded to Incoterms are all correlated to export performance, including both financial and strategic performance as well as manager satisfaction with export activities.

First, we were able to show that companies that use Incoterms more frequently have a better export performance (PH1). In fact, this reflects the raison d'être of Incoterms: to facilitate international trade and to clarify the respective responsibilities of the different parties (Sriro, 1993). Thus, it is relatively logical that, since Incoterms tend to reduce litigation, using them intensively would be correlated with export performance.

The second preliminary hypothesiscompanies with a greater knowledge of Incoterms have a better export performance-refers to the ability of export managers to choose Incoterms on their own. This ability was considered by Jacquet (2000) to be an important factor in competitiveness. In addition, a more in-depth statistical analysis shows that companies with a greater knowledge of Incoterms tend to take environmental factors into account more when selecting Incoterms. Such consideration, as shown by the validation of WH11, constitutes a performance factor. Thus, a better understanding of the stakes and the factors to be considered tends to improve Incoterm choices and thus be positively correlated with companies' export performance at all levels.

The third preliminary hypothesis, which validated the correlation between the importance accorded to Incoterms and export performance, also seems to be connected to the previous two elements. Clearly, given that we have shown that the importance accorded to Incoterms is positively correlated with export performance, we can also show that the better the knowledge of Incoterms, the more importance is accorded to them. This connection $(p=0.000)$ is particularly strong; the correlation coefficient shows that "Incoterm knowledge" explains 34\% of the "importance accorded to Incoterms". If knowledge of Incoterms tends to increase the importance accorded to these terms, the latter tends to increase the Incoterm use frequency, which in turn is positively correlated with export performance.

Thus, given the validation of the first three preliminary hypotheses, each aspect is individually correlated to export performance (Figure 2). Still, a more in-depth examination of these variables shows that they are also interconnected. The importance that a company accords to Incoterms tends to increase with its knowledge, of Incoterms and with their use frequency. This connection is, however, indirect; there is no direct connection between Incoterm knowledge and Incoterm use frequency.

Figure 1. Links between the preliminary hypotheses

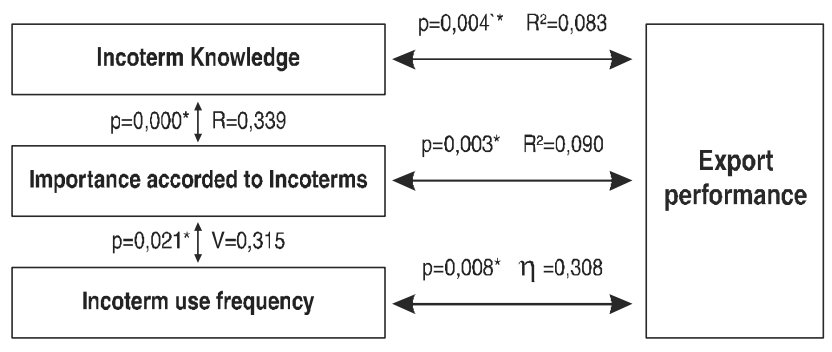

Following the analysis of the preliminary hypotheses, let us now turn to the results obtained for the working hypotheses.

\subsection{Analysis of the working hypotheses}

As we have seen above, four of our eleven working hypotheses could be validated by statistical analysis. Thus, the relationship between export performance and international experience (WH1), client negotiating power (WH5) and competitive intensity in the destination country (WH9) has been demonstrated. In addition, the validation of WH11 confirms the idea that companies that take the pertinent environmental factors into consideration when selecting Incoterms have a better export performance than those that do not.

One should note that the validation of the first working hypothesis confirms that taking international experience into account when selecting Incoterms affects export performance, not the experience in itself. In fact, no significant correlation appears to exist between a company's export history 
and the consideration of environmental factors, indicating that what is important is not the number of years of export experience, but rather the act of taking this experience into account when selecting Incoterms. Thus, regardless of the number of years of export performance, taking this experience into account is a pertinent environmental factor that is positively correlated with export performance. Though considering international experience has a positive effect on financial performance, strategic performance, and satisfaction with export activities, as well as overall performance, considering client negotiating power tends to affect only the three aspects of the last category.

The ninth WH shows that companies that take the competitive intensity in the destination country into consideration when selecting Incoterms have a better export performance than those that do not. Clearly, the level of competition in a country tends to influence Incoterm choices by pushing companies to propose a group D Incoterm when competition is high. It is interesting to note that although considering this variable correlates positively with export performance financially, strategically and globally, it does not correlate with manager satisfaction with export activities. This particularity can be partially explained by the preferences of export managers, who seem to favor the Incoterms EXW or FOB, rather than DDP. Since considering competitive intensity sometimes leads managers to attempt to counter the heavy competition by choosing a group D Incoterm, these managers do increase the export performance of their company. However, they also increase the headaches associated with having total responsibility for the shipment, which could explain their dissatisfaction.

Finally, the validation of WH 11 allows us to respond adequately to the research question of this study by demonstrating that companies that take pertinent environmental factors into consideration when selecting Incoterms have a better export performance than those that do not. It seems quite clear that considering environmental factors increases export performance financially, strategically and globally. This result is fundamental and underlines the complementarities of the various factors and the usefulness of analyzing the environment as a whole.

\subsection{Training as a catalyst}

Given the results of this study, the consideration of international experience, client negotiating power and competitive intensity in the destination country appears to be essential. Other factors can also be considered. However, statistical analysis shows that as their knowledge of Incoterms increases, export companies tend to take their international experience, negotiating power and environment into account to a greater degree. The tendency of the "knowledge" variable to increase with the consideration of the environment can also be attributed to the "Incoterm importance" variable, since as the importance accorded to Incoterms increases; companies tend to take environmental factors into account more.

Consequently, one of the key elements for progress would seem to be to train managers to use the Incoterm tool. Training courses should increase managers' knowledge of the subject, which, as demonstrated above, is positively correlated with the importance that managers accord to Incoterms and to their consideration of environmental factors when selecting Incoterms. This in turn could increase export performance. Such manager training courses should be offered not only to transportation technicians, but also to those who negotiate international contracts.

\section{Conclusion, Limitations and Future Research Avenues}

The objective of this study was to analyze the impact of the environment on Incoterm choices and export performance. We have shown that considering pertinent environmental factors when selecting Incoterms is a factor that is positively correlated to export performance, which reflects management's ability to understand the legal environment of the company. An important element of decision making in the field of international transportation, the choice of Incoterms appears to be also a key factor in the success of export activities.

In addition, we have shown the importance of approaching Incoterm selection systemically, considering the entire set of pertinent environmental factors jointly. Although international experience, client negotiating power and competitive intensity 
all correlate with export performance, the validation of WH 11, the keystone of this study, leads us to conclude that companies that consider environmental factors when selecting Incoterms have a better export performance, thus making Incoterms themselves - and by extension, Incoterm choice - a fundamental part of company strategy. Furthermore, the tests of the preliminary hypotheses have shown that Incoterm use frequency, Incoterm knowledge, and the importance accorded to Incoterms are all positively correlates with export performance. Analyzing the relationship between these three variables has highlighted the fact that knowledge of Incoterms is correlated with the importance accorded to them, which in turn, is correlated with their use frequency. This interaction only emphasizes the catalyzing role of manager training.

Our research was limited by a certain number of elements which should be explained in order to judge the true value of our results. First, this study focused solely on the exporter's perspective, leaving the importer out of the equation entirely. Including the importer's perspective would have allowed a more global picture of the respective stakes of both parties to be drawn, which would have contributed to a better understanding of the negotiation phase. Second, there were also several constraints related to our methodology. Although our use of the Industry Canada database on a data that come only from Quebec, whose registration process is strictly a voluntary one, does not seem to have lead to any major complications, the fact that export performance was evaluated by the managers themselves could have introduced a certain bias. It may have been better to adopt quantifiable operational measurements for each company, which would have allowed us to evaluate the export performance more objectively. However, time constraints and company reticence to provide quantifiable performance data were undeniable obstacles to the writing of such an article. Finally, since this research is based on survey data and it does not track the performance of companies over years, we could not perform causality tests. We believe that tests such as Granger causality tests could be used in future research.

Given the low number of publications on the subject, we consider that the results obtained for this study open a new avenue of research that should now be explored more completely. Clearly, many studies taking up where this article leaves off are possible. First, a comparative study from the importer's perspective would help to validate the results obtained in this study, notably in terms of the environmental factors. By analyzing the respective preoccupations of both parties, such a study would help to improve understanding of the stakes inherent to Incoterms. In addition, a similar study conducted in Europe, where the Incoterm knowledge is greater, would no doubt provide relevant information. It would obviously be beneficial to compare European and North American practices, analyzing the differences in the use of this tool, while also verifying whether or not a correlation exists between Incoterm selection and export performance on the other side of the Atlantic. Research into the different countries' perceptions of the rules and their interpretation of the different Incoterms, examining the impact of culture on Incoterm selection, could also prove quite interesting. Studying the cultural aspects of the questions surrounding Incoterm use would also allow the texts of the International Chamber of Commerce to be improved by standardizing the understanding and application of these reference documents throughout the world. Moreover, it would also be interesting to study the impact of a long term relationship between buyers and sellers in order to determine whether the decision becomes more routine as the relationship develops over time.

Finally, although the next revision of Incoterms has not yet been announced, it would be worthwhile to anticipate such an announcement since doing so would encourage research into the possibility of integrating new safety constraints into the Incoterms. The existing Incoterms do not take security programs into account and do not define the respective responsibilities of each party with regard to their conformity with the rules of the programs now in effect. This is likely to become a major challenge in the years to come.

\section{Acknowledgements}

Thanks are due to the referees for their valuable comments. 


\section{References}

Aaby, N. and Slater, S. (1989) Management Influences on Export Performance: A Review of the Empirical Literature 1978-1988. International Marketing Review 6, pp. 7-27.

Aharoni, Y., Maimon, Z. and Segev, Z. (1978) Performance and Autonomy in Organizations: Determining Dominant Environmental Components. Management Science 24, pp. 949-959.

Ali, Y. (2004) Impact of Firm and Management Related Factors on Firm Export Performance. Journal of Asia Pacific Marketing 3, pp. 5-20.

Anderson, C. and Paine, F. (1975) Managerial Perceptions and Strategic Behaviour. Academy of Management Journal 18, pp. 811-823.

Baldauf, A., Cravens, D., Wagner, U. (2000) Examining Determinants of Export Performance in Small Open Economies. Journal of World Business 35, pp. 61-79.

Brouthers, K. (1995) The Influence of International Risk on Entry Mode Strategy in the Computer Software Industry. Management International Review 35,pp. 7-28.

Calantone, R., Daekwan, K., Schmidt, J. and Cavusgil, T. (2006) The Influence of Internal and External Firm Factors on International Product Adaptation Strategy and Export Performance: A Three Countries Comparison. Journal of Business Research 59, pp. 176-185.

Chetty, S. and Hamilton, R. (1993) Firm-level Determinants of Export Performance: A Meta-analysis". International Marketing Review 10, pp. 26-34.

Chevalier, D. (2000) Incoterms 2000: Tous les mécanismes ». MOCI. Hors série. 50 pages. Paris.

Cooper, K. and Kleinschmidt, E. (1985) The Impact of Export Strategy on Export Sales Performance. Journal of International Business Studies 16, pp. 37-55.

Debattista, C. (1995) Incoterms in Practice. ICC Publishing. Paris.

Dill, W. (1958) Environment as an Influence on Managerial Autonomy. Administrative Science Quarterly 2, pp. 409-443.

Dominguez, L. and Sequeira, C. (1993) Determinants of LDC Exporters' Performance: A Cross-national Study. Journal of International Marketing 24, pp. 19-40.

Duncan, R. (1972) Characteristics of Organizational Environments and Perceived Environmental Uncertainty. Administrative Science Quarterly 17, pp. pp. 313-327.

Erramilli, K. (1992) Influence of Some External and Internal Environmental Factors on Foreign Market Entry Mode Choice in Service Firms. Journal of Business Research 25, pp. 263-276.

Freudmann, D. (1999) Traders get a brand-new bible. Journal of Commerce, September 9, p. 1.
Gooley, T. (2000) Incoterms 2000: What the Changes Mean to You. Logistics Management and Distribution Report 39, p. 49.

Holley, D. and Haynes, R. (2003) The Incoterms Challenge: Using Multi-media to Engage Learners. Education $\mathcal{E}$ Training 45, pp. 392-401.

Jacquet, L. (2000) Connaître et employer les Incoterms. In Incoterms 2000: Tous les mécanismes, MOCI. Hors série. 50 pages. Paris.

Jimenez, G. (1998) Incoterms Questions and Answers. ICC Publishing.166 pages. Paris.

Katsikeas, C., Leonnidou, L. and Morgan, R. (2000) FirmLevel Export Performance Assessment: Review, Evaluation and Development. Journal of the Academy of Marketing Science 28, pp. 493-511.

Katsikeas, C., Piercy, N. and Ioannidis, C. (1996) Determinants of Export Performance in a European Context. European Journal of Marketing 30, pp. 6-35.

Lages, L., and Montgomery, D. (2004) Export performance as an antecedent of export commitment and marketing strategy adaptation: evidence from small and mediumsized exporters. European Journal of Marketing 38, pp. 1186-1214.

Krause, D., Scannell, T., (2002)« Supplier development practices: Product and service-based industry comparisons ", Journal of Supply Chain Management, , pp. 13-21.

Lawrence, P. and Lorsch, J. (1967) Organization and Environment. Harvard Business School. Boston.

Legrand, G. and Martini, H. (1999) Management des opérations de commerce international. Dunod. $4^{\text {th }}$ Edition. 423 pages. Paris.

Lin, C. (2006) A Study on the Organization Innovations in Taiwan's Logistics Industry, The Business Review, Cambridge, 5, pp. 270-277

Luffman, G. (1996) Strategic Management: An Analytical Introduction. Blackwell. 499 pages. Oxford.

Lynch, R. (1997) Corporate Strategy. Pitman Publishing. London.

Madsen, T. (1989) Successful Export Marketing Management: Some Empirical Evidence. International Marketing Review 6, pp. 41-57.

Malhotra, N., Décaudin, J.M., and Bouguerra, A. (2004) Études marketing avec SPSS. $4^{\text {th }}$ Edition. Pearson Education. 664 pages. Paris.

Mayrhofer, U. (2002) La culture nationale du pays d'origine et le choix du mode d'entrée sur les marchés étrangers. Management International 6, pp. 23-33.

OECD (2002) Supply Chains and the OECD Guidelines for Multinational Enterprises. 
Osland, G., Taylor, C. and Zou, S. (2001) Selecting International Modes of Entry and Expansion. Marketing Intelligence $\mathcal{E}$ Planning 19, pp. 153-161.

Pan, Y. and Tsé, D. (2000) The Hierarchical Model of Market Entry Modes. Journal of International Business Studies 31, pp. 535.-553.

Ramberg, J. (1999) ICC Guide to Incoterms 2000 : Understanding and Practical Use. ICC Publishing. 200 pages. Paris.

Rasheed, H. (2005) Foreign Entry Mode and Performance: The Moderating Effects of Environment. Journal of Small Business Management 43, pp. 41-54.

Sanchez, R. and Heene, A. (1997) Managing for an Uncertain Future: A Systems View of Strategic Organizational Change. International Studies of Management E Organization 27, pp. 21-42.

Sanjeev, A. and Sridhar, R. (1992) Choice of Foreign Market Entry Mode: Impact of Ownership, Location and Internalization Factors. Journal of International Business Studies 23, pp. 1-27.

Sriro, A. (1993) Incoterms - a Quick Reference. East Asian Executive Reports 15, pp. 21-23.
Thirkell, P. and Dau, R. (1998) Export Performance: Success Determinants for New-Zealand Manufacturing Exporters. European Journal of Marketing 32, p. 813.

Tookey, D. (1964) Factors Associated with Success in Exporting. Journal of Management Studies 1, pp. 48-66.

Tsé, D., Pan, Y. and Au, K. (1997) How MNCs Choose Entry Modes and Form Alliances: The China Experience ". Journal of International Business Studies 28, pp. 779-805.

Walsh, P. (2005) Dealing with the Uncertainties of Environmental Change by Adding Scenario Planning to the Strategy Reformulation Equation. Management Decision 43, pp. 113-122.

White, S., Griffith, D. and Ryans, J. (1998) Measuring Export Performance in Services Industries. Journal of Marketing Review 15, pp. 188-204.

Zou, S. and Stan, S. (1998) The Determinants of Export Performance: A Review of the Empirical Literature between 1987 and 1997. International Marketing Review 15, pp. 333-356.

Zou, S., Taylor, C., and Osland, G. (1998) The EXPERF Scale: A Cross-national Generalized Export Performance Measure. Journal of International Marketing 6, pp. 37-58.

Nicolas Hien obtained his M.Sc. in logistics at HEC Montreal. He is Project Director at 4L2 Group, Vicepresident of the APICS Montreal Chapter, member of Supply Chain and Logistics Canada (SCL), chronicler for Logictics Magazine and lecturer at HEC Montreal. His expertise is in supply chain management, inventory management and the transportation sector. During the last few years, he has managed projects related to the design of distribution centers, network optimization, routing and process improvement in several industries. In 2006, he obtained the James Eckler Award from SCL Canada and the A.M. Stevens Award from the Canadian Transportation Research Forum.

Gilbert Laporte obtained his Ph.D. in Operations Research at the London School of Economics in 1975. He is Professor of Operations Research at HEC Montréal, Director of the Canada Research Chair in Distribution Management, and a adjunct Professor at Molde University College, the University of Bilkent, the University of Alberta and Université Laval. He is also a member of the Centre for Research on Transportation (serving as director from 1987 to 1991) and founding member of the Groupe d'études et de recherche en analyse des decisions (GERAD). He has authored or coauthored 15 books, as well as more than 300 scientific articles in combinatorial optimization, mostly in the areas of vehicle routing, location and timetabling. He has received many scientific awards including the Pergamon Prize (United Kingdom) in 1987, the 1994 Merit Award of the Canadian Operational Research Society, the CORS Practice Prize on two occasions. In 1999, he obtained the ACFAS Jacques-Rousseau Prize for Interdisciplinarity and the President's Medal (Operational Research Society, United Kingdom). In 2001, he was awarded the Pedagogy Prize by HEC Montréal. He has been a member of the Royal Society of Canada since 1998, and Fellow of INFORMS since 2005. In 2007 he received the Innis-Gerin medal from the Royal Society of Canada.

Jacques Roy is a professor of Logistics and Operations Management at HEC Montreal where he is also Director of the Carrefour logistique, a university-industry forum on Supply Chain Management. He is the Director of the research group Chaine that is conducting research activities in the field of Supply Chain 
Management. He was also Director, Research and Publication and Director, Training, at the Montreal based International Aviation Management Training Institute. Professor Roy graduated with a B.Sc. from the Royal Military College in Saint-Jean and completed his education with an M.B.A. and a Ph.D. in Business Administration at HEC Montréal. Prior to his teaching career, Dr. Roy was employed as an aerospace engineering officer with the Canadian Armed Forces. He also possesses many years of experience as a management consultant with several large Canadian corporations and governmental organizations. His expertise lies in the areas of logistics and transportation management. Dr. Roy has authored several articles and publications in this subject area, and has participated in many conferences at both national and international levels. 